\title{
The Normative Molecule: Patent Rights and DNA
}

Saurabh Vishnubhakat

Texas A\&M University School of Law, sv10@law.tamu.edu

Follow this and additional works at: https://scholarship.law.tamu.edu/facscholar

Part of the Intellectual Property Law Commons, Law and Philosophy Commons, and the Legal Ethics and Professional Responsibility Commons

\section{Recommended Citation}

Saurabh Vishnubhakat, The Normative Molecule: Patent Rights and DNA, 26 HYLE 55 (2020). Available at: https://scholarship.law.tamu.edu/facscholar/1436

This Article is brought to you for free and open access by Texas A\&M Law Scholarship. It has been accepted for inclusion in Faculty Scholarship by an authorized administrator of Texas A\&M Law Scholarship. For more information, please contact aretteen@law.tamu.edu. 


\title{
The Normative Molecule: Patent Rights and DNA
}

\author{
Saurabh Vishnubhakat
}

\begin{abstract}
Throughout the biotechnology age, fears about the distortionary effects of property and other legal institutions upon the health and selfdetermination of individuals and societies have accompanied more popularly sensational fears about unscrupulous choices within the scientific community itself. Still, for most of that time the prevailing legal regime both in the United States and in Europe remained generally permissive of ownership of, and exclusionary power over, the fruits of much biomedical research, though this leniency took different forms and came about in different ways. In particular, the policy of the United States Patent and Trademark Office to grant patents on genetic compositions such as DNA sequences produced an extensive landscape of legal rights that would eventually provoke a backlash in both legal and popular opinion during the Myriad Genetics lawsuit. This case study examines the normative dimension of patent rights over isolated DNA sequences through the lens of the Myriad case, discussing the institutional context in which the case arose and identifying ethical lessons that the case offers.
\end{abstract}

Keywords: DNA, genetics, patents, Myriad, innovation, ethics.

\section{Introduction}

\subsection{The magic microscope}

In April 2011, the U.S. Department of Justice did something it had never done before, and it was a sign of things to come. The Solicitor General, the Justice Department lawyer who represents the U.S. government in lawsuits, came personally to argue the government's position in a patent case before the Federal Circuit Court of Appeals ('Federal Circuit', in the following). Ordinarily, the Solicitor General would have left a case like this to be argued by the solicitor of the specific agency that deals regularly with the subject matter of the lawsuit, especially in a complex field like patent law. Indeed, the 
Solicitor of the Patent Office regularly does this in Federal Circuit cases. At most, the Solicitor General might have sent a lawyer from his Justice Department staff if the case was more important than usual. Even then, agency lawyers from the Patent Office (who know the subject matter) and Justice Department lawyers (who coordinate legal policy across the executive branch) would have met and planned out the strategy together. What made this case special, and what did the Solicitor General's appearance portend?

The answer came from a confluence of three unusual problems, and all of them were related to the underlying science of DNA and to the question of expertise in genetic and genomic science. The lawsuit was about whether certain patents held by Myriad Genetics were valid. Myriad was founded in the 1990s by scientists at the University of Utah who, like others at the time, were trying to isolate the gene or genes associated with elevated risks of developing breast and ovarian cancer. The Myriad-Utah team, which also included researchers from the National Institutes of Health and elsewhere, were the first to isolate and publish the sequence of the BRCA1 and BRCA2 genes. The team then sought patents variously related to these gene sequences, and the Patent Office granted the patents. The Public Patent Foundation (PUBPAT) and the American Civil Liberties Union (ACLU), concerned about the effects of these kinds of patents, brought a lawsuit in 2009 to invalidate Myriad's patents. The lawsuit was assigned to Judge Robert Sweet of the U.S. District Court for the Southern District of New York. This was the case now pending on appeal in the Federal Circuit, following Judge Sweet's decision in the district court.

One problem was that the Patent Office continued to disagree with the Justice Department on a fundamental matter of patent law and policy. That was whether isolated DNA sequences themselves fall within the broad scope of patent-eligible subject matter - i.e., whether isolated DNA sequences even belong in the patent system. ${ }^{1}$ The disagreement mattered. The Patent Office sits in the Department of Commerce and is an executive-branch agency. Ordinarily, the Patent Office has the power to grant or deny patent applications, and it has more expertise about science and technology than most other parts of the executive branch; certainly it has more expertise on patent law than any other agency. Meanwhile, the Solicitor General's office at the Justice Department sets legal policy across the executive branch. So when the Patent Office has one view about proper patent policy, the Solicitor General's office has a different view, and both sides have debated an impasse: who should prevail?

Who does prevail is simple: the Solicitor General. But is that a good and sensible rule? Perhaps the expertise of the Patent Office means that its view should be the official view of the U.S. government on all patent matters. Or perhaps the greater experience that the Solicitor General has coordinating 
across multiple specialized disciplines (like patent law, tax law, environmental protection, securities regulation, etc.) means that its view should be the official view of the government. The superior policy authority of the Solicitor General's office means that although it should, and does, listen to expert agencies and learn from them, it does not defer to them. The Solicitor General still makes an independent decision and, importantly, expects the agencies in the executive branch, like the Patent Office, to accept that decision and sign on to it.

That last expectation did not come to pass this time. The Solicitor of the Patent Office did not sign the government's brief, indicating continued and unreconciled disagreement with the Solicitor General about what the official position of the government ought to be, and indicating that disagreement publicly. It is not clear whether this played any role in the Solicitor General's decision to appear in the case. However, his unprecedented appearance while this intra-governmental disagreement was still a live issue highlighted the Patent Office's contrary position and made it an important sticking point. Oral arguments both at the Federal Circuit and later at the Supreme Court brought up this fundamental dispute between the expert opinion of the specialist agency and the official opinion of the generalist authority.

A second problem that complicated matters further was that the Patent Office was not the only executive-branch institution that had relevant scientific expertise, and even the experts disagreed. The position of the National Institutes of Health (NIH) diverged from that of the Patent Office. The $\mathrm{NIH}$ is an agency within the Department of the Health and Human Services and supports scientific research through extensive federally funded research grant programs, especially research in the life sciences. Thus, like the Patent Office, the NIH had significant claims to expertise at least in the underlying subject matter of Myriad's patents, even if it could not necessarily claim the same level of expertise as the Patent Office about patent policy. For this very reason, inter-agency discussions to consider policy questions are structured to consider all relevant positions across the executive branch before the government's official position is decided. And this, too, underscored the importance of the Solicitor General himself entering an appearance to argue in the Federal Circuit.

A third and more elusive problem was that the Federal Circuit itself was potentially at odds with the Supreme Court, either about the disputed patent policy matter in general, about the Myriad case in particular, or both. Federal judges are legal generalists, and the way they are selected - political nomination by the President and confirmation by the Senate - does nothing in particular to promote expertise in science and technology. The Federal Circuit is different. Created in 1982, the Federal Circuit Court of Appeals hears appeals from all patent lawsuits in the entire country. Other circuit courts in 
the federal system hear appeals only from their respective geographic regions. The Federal Circuit's jurisdiction was defined by subject matter rather than geography in order to promote uniformity and expertise on matters of patent law.

As a result, the Federal Circuit has extensive experience with patent law and receives hundreds of patent cases each year. Federal Circuit judges are steeped in patent doctrine, and of those who come to the bench, many have formal education in physical science or engineering disciplines. By contrast, the Supreme Court receives thousands of requests but chooses to hear fewer than a hundred cases each year, and of these, it is unusual that even one or two cases a year are about patent law. As for Supreme Court Justices themselves, if there is a field in which they develop expertise before coming to the bench, it is usually constitutional law or administrative law, certainly not patent law.

So just as the Patent Office came to the dispute with greater expertise but less authority than the Solicitor General, the Federal Circuit came to the case with greater technical and doctrinal expertise but less judicial authority than the Supreme Court. And unlike the executive branch, the two courts could not directly confer and debate the case. The Federal Circuit would have to decide the appeal for itself first, then wait to see whether the Supreme Court would take the case and, if so, how the Court would rule. So the direct involvement of the Solicitor General right at the Federal Circuit highlighted the case even more starkly for the Supreme Court's consideration.

So far, this may seem like a story about competing claims for power and claims of expertise, but not especially a story about genetic science itself. The clearest evidence against this came in the first minute of the argument of Neal Katyal, the Acting Solicitor General. The Myriad patents in question contained various DNA-related claims, but what eventually drove the lawsuit was a distinction between isolated fragments of genomic DNA (gDNA) and isolated fragments of complementary DNA (cDNA). The structure of these DNA fragments, especially their nucleotide sequences, were, at some basic level, the result of nature's handiwork. For this reason, the PUBPAT and ACLU challengers believed that both of these types of isolated DNA sequences, genomic as well as complementary, were not patent-eligible at all. ${ }^{2}$

The government took a more modest position. gDNA was not patenteligible, agreed Katyal, because its nucleotide sequence does occur in nature in that portion of the chromosome itself where the relevant gene is located but cDNA was eligible because its nucleotide sequence does not occur naturally. When cDNA is synthesized from mature messenger RNA (mRNA), the introns have already been removed from the RNA transcript, leaving only exons. Thus, the removal of introns changes the nucleotide sequence from 
what occurs in nature to something different, akin to a magazine from which all the advertisement pages have been torn out.

To illuminate this distinction, Katyal invited the court to imagine a 'magic microscope' that could zoom in on nucleotide sequences. Using such a microscope, the sequence of an isolated gDNA fragment could be compared to the sequence of wild-type gDNA from the same gene in vivo. The comparison would reveal that the sequences were the same. Meanwhile, a comparison between an isolated cDNA fragment and any corresponding wild-type DNA or RNA would reveal that the sequences were not the same (because the introns had been removed).

This metaphor of the magic microscope was rhetorically powerful. It met the scientific expertise of both sides in the dispute with the government's own scientific expertise, but reflected shrewd choices about which scientific details should matter. The magic microscope argument pointed the court toward the sequence information contained in the BRCA1 and BRCA2 genes, and the normative implications of that information, rather than solely the chemical structure of the DNA that constituted the genes. It urged scientific and lay audiences: don't miss the forest for the trees. DNA is a chemical compound, yes, but that is not all it is.

\subsection{Patent rights and the special case of DNA}

Before going further, it is helpful to clarify the terms a bit. How does the intellectual property framework of patents work, and does DNA pose special problems for patent law? Intellectual property can be understood most simply by analogy to more familiar kinds of property. For example, a company that owns a car and a traveler who rents the car both hold property interests in the same underlying thing: the car. Where the underlying thing is some new and useful invention, the property interests people can hold over that invention are called patent rights, and they are one form of IP. (Other forms include copyrights and trademarks.)

What do these property interests entail? The interest of the company that owns the car includes various rights, like the right to remove unauthorized drivers from the car, the right to paint the car red, the right to sell the car, and so on. The interest of the traveler renting the car also includes rights, but understandably, these are fewer than - and, in some sense, inferior to - the owner's rights, as the rental agreement spells out.

Patent rights start out similarly. An inventor who holds a patent on her invention - say, a special wooden chair - can for a limited period of time exclude others from making the chair, using it, selling or offering to sell it, or importing it into the country. (After that time, the chair enters the public 
domain, and anyone can use it freely.) But what does it mean to think of the chair as an invention rather than just another tangible thing?

It means that if someone buys lumber, saws the lumber into parts, and assembles those parts into something that matches the patented chair, then he is infringing the inventor's patent right. The patent covers not just one specific physical chair, but all objects that shares the particular features of the chair. The infringer used his own materials, tools, and effort. Indeed, he has his own property interests in those things. Yet his rights do not extend to making the patented chair as he has done. This makes patents an extraordinary kind of property right, which are granted only as a reward for inventing something new and useful, something society would not have received (or would not have received as soon) without the inventor's contribution. Even with the patent's restrictions, society is still better off than if the new chair had never been invented.

Still, one can easily imagine how this setup can get messy where the invention has important social and dignitary implications, such as with DNA. It is one thing to grant patents as a reward for inventing a new organic solvent for degreasing engines. Is it the same to grant patents for discovering a gene sequence, or designing a new one? They are both chemical compounds, but subjecting them to private property rights can have dramatically different effects.

For several decades, the Patent Office saw no problem and granted generelated patents routinely. The idea was that taking away the patent reward for DNA-related inventions would slow down investment in those inventions, harming society in the long run. This explanation assumed a lot about the nature and drivers of invention. Those assumptions are what had allowed Myriad to obtain their patents and what PUBPAT and the ACLU had to attack, at least as to DNA patents.

\section{Ownership of DNA Through Patents}

\subsection{The Myriad genetics patents}

Although PUBPAT and the ACLU were challenging fifteen claims across seven different Myriad patents, three claims are particularly relevant for the present purposes. ${ }^{3}$ These are three of the composition claims from U.S. Patent No. 5,747,282 entitled '17Q-linked breast and ovarian cancer susceptibility gene'. The Federal Circuit and, later, the Supreme Court evaluated these three claims as being representative of all the composition claims in dispute. 
By law, the claims in a patent can cover subject matter from any of four categories: compositions of matter, processes (which in patent law are synonymous with methods), machines, and manufactures (35 U.S.C. $\mathbb{S} 101$ ). Here, the composition claims asserted ownership over identified isolated DNA sequence molecules themselves. The legal logic was that although a given DNA sequence may be quite large chemically, it is still ultimately a molecule and thus a composition of matter. The method claims, meanwhile, asserted ownership over ways of doing things related to the identified DNA sequences, such as making comparisons between the claimed DNA sequences and other DNA sequences or screening potential cancer therapies. These method claims were separately found invalid.

Considering the actual language of the composition claims that the Federal Circuit took as representative, the following are claims 1, 2, and 5 of Patent No. 5,747,282:

1. An isolated DNA coding for a BRCA1 polypeptide, said polypeptide having the amino acid sequence set forth in SEQ ID NO:2.

2. The isolated DNA of claim 1, wherein said DNA has the nucleotide sequence set forth in SEQ ID NO:1.

5. An isolated DNA having at least 15 nucleotides of the DNA of claim 1.

The terms 'SEQ ID NO:1' and 'SEQ ID NO:2' refer to sequences that are fully spelled out later in the patent. For example, 'SEQ ID NO:2' refers to a particular amino acid sequence corresponding to a BRCA1 polypeptide; the sequence is Met-Asp-Leu-Ser-Ala-Leu-... and so on. Thus, claim 1 covers any nucleotide sequence that codes for the polypeptide having that amino acid sequence. As biochemists know, the genetic code is redundant such that the same amino acid can be coded by multiple nucleotide triplets. For example, the codons CGT, CGC, CGA, CGG, AGA, and AGG all code for arginine. The syntax of claim 1 - defining the DNA sequence by reference to the polypeptide sequence - ensures that all relevant redundancies are covered. Claim 2 then goes further by specifying one example of a nucleotide sequence, the one set forth in SEQ ID NO: 1, that codes for the amino acid sequence of SEQ ID NO:2. Claim 5 broadens the scope of the patent right even further by claiming all sub-sequences of claim 1 that are 15 nucleotides or longer.

To understand the scope of how broadly these claims sweep, consider just the first six amino acids that are listed above from SEQ ID NO:2, Met-AspLeu-Ser-Ala-Leu. The different nucleotide triplets that code for each amino acid are as follow: 


\begin{tabular}{lllllllll}
\hline Amino Acid & Codons & \multicolumn{1}{l}{ Codons that Code for that Amino Acid } \\
\hline Met (Methionine) & 1 & ATG & & & & & \\
Asp (Aspartic acid) & 2 & GAC & GAT & & & & \\
Leu (Leucine) & 6 & CTA & CTC & CTG & CTT & TTA & TTG \\
Ser (Serine) & 6 & AGC & AGT & TCA & TCC & TCG & TCT \\
Ala (Alanine) & 4 & GCA & GCC & GCG & GCT & & \\
Leu (Leucine) & 6 & CTA & CTC & CTG & CTT & TTA & TTG \\
\hline
\end{tabular}

From these redundancies, this six-peptide fragment alone could be coded by 1,728 different DNA sequences $(1 \times 2 \times 6 \times 6 \times 4 \times 6)$, each merely 18 nucleotides in length. For example, the following is but one of the 18-nucleotide sequences that would code for the Met-Asp-Leu-Ser-Ala-Leu polypeptide sequence. Moreover, each 18-nucleotide sequence would have 10 subsequences that were at least 15 nucleotides long.

\begin{tabular}{|c|c|c|c|c|c|c|c|c|c|c|c|c|c|c|c|c|c|}
\hline \multicolumn{3}{|c|}{ Met } & \multicolumn{3}{|c|}{ Asp } & \multicolumn{3}{|c|}{ Leu } & \multicolumn{3}{|c|}{ Ser } & \multicolumn{3}{|c|}{ Ala } & \multicolumn{3}{|c|}{ Leu } \\
\hline A & $\mathrm{T}$ & G & G & A & $\mathrm{T}$ & $\mathrm{C}$ & $\mathrm{T}$ & A & $\mathrm{T}$ & $\mathrm{C}$ & $\mathrm{T}$ & G & $\mathrm{C}$ & $\mathrm{T}$ & $\mathrm{C}$ & $\mathrm{T}$ & A \\
\hline \multicolumn{18}{|c|}{ 15-nucleotide sequence } \\
\hline \multicolumn{18}{|c|}{ 15-nucleotide sequence } \\
\hline \multicolumn{18}{|c|}{ 15-nucleotide sequence } \\
\hline \multicolumn{18}{|c|}{ 15-nucleotide sequence } \\
\hline \multicolumn{18}{|c|}{ 16-nucleotide sequence } \\
\hline \multicolumn{18}{|c|}{ 16-nucleotide sequence } \\
\hline \multicolumn{18}{|c|}{ 16-nucleotide sequence } \\
\hline \multicolumn{18}{|c|}{ 17-nucleotide sequence } \\
\hline \multicolumn{18}{|c|}{ 17-nucleotide sequence } \\
\hline \multicolumn{18}{|c|}{ 18-nucleotide sequence } \\
\hline
\end{tabular}

This means that Claim 5 multiplies the 1,728 different DNA sequences to 17,280 different DNA sequences over which the claims assert ownership. As the length of the claimed polypeptide grows, the permutations of codons, the number of sub-sequences that are at least 15 nucleotides in length, and the overall number of isolated DNA sequences that are covered by the patent grows exponentially. The upshot of this broad patent scope is that composition claims directly covering isolated DNA sequences on the scale of a gene like BRCA1 or BRCA 2 are powerful legal instruments, and reflect the high stakes of the Myriad case.

In practical terms, the broad exclusionary power of patent rights over DNA as a composition means that even some new use for the patented DNA sequence or some new method involving the patented DNA sequence - a use or method that was unknown at the time of patenting - would still be encumbered by the patent rights that Myriad held. It would be as if someone walked around a piece of uncharted land, mapped it, and acquired a property 
right over it. Minerals in the land or oil below it would belong to the property holder, just as much as the land itself does, even if the owner had no knowledge of those additional resources. Indeed, this is a simplified example of how property rights in land actually work, though it is highly contested whether it is appropriate for the law to treat genetic resources in the same way.

\subsection{The 'product of nature' doctrine in patent law}

The Myriad case itself had already reached a significant milestone by the time it arrived at the Federal Circuit. The federal district court in Manhattan, where the case began, had given the challengers of the Myriad patents a clear victory. They had standing to file the lawsuit in the first place (a technical issue of court procedure but very important in public interest lawsuits like this). And according to the district court, all of the composition claims (as well as all of the method claims) of the patents in question were patentineligible. Myriad had come to the Federal Circuit to seek reversal of these judgments. Meanwhile, the direct and personal involvement of the Solicitor General, discussed above, meant that continued interest in the case - including review by the Supreme Court - was likely. The composition claims, whose scope swept so broadly, were the especially contentious element of the case. The Federal Circuit would have to both decide and explain which approach to take in evaluating the patent-eligibility of claims that covered isolated sequences of genomic DNA (gDNA), complementary DNA (cDNA), or both.

To do so, the Federal Circuit would have to apply the 'product of nature' doctrine. A longstanding rule of patent eligibility, the doctrine provides that natural products themselves are not allowed to be patented, though other things that build on products of nature may be eligible. How a decision maker might apply this rule depends to some extent on what the justifications for the rule are understood to be. One justification is that patent rights are an incentive and reward for those who invented the subject matter of the patent, but products of nature are not invented at all; they arise from natural processes without human design or intervention. Another is that patent rights exist to promote innovation, and because natural products are among the raw materials from which innovation is conducted, they should remain unencumbered for public use.

The first explanation is more analytical and emphasizes conditions and criteria for deciding whether something is a product or nature and therefore ineligible for patenting or is not a product of nature and so may, indeed, be eligible. The second explanation is more instrumental and emphasizes the desirability of the outcomes that are likely to come about based on whether 
something is deemed an ineligible product of nature or not. In practice, these explanations are not mutually exclusive. Courts rely in various ways and to varying degrees on both explanations as they apply the doctrine in accordance with traditional methods of legal analysis.

An important element of that analysis is respecting prior precedents. To grasp the product of nature doctrine, two precedents are especially helpful. One is the Supreme Court's decision in Funk Brothers $v$. Kalo Inoculant (Funk Brothers 1948). In the Funk Brothers case, the patent was directed toward a mixture of nitrogen-fixing bacteria from the genus Rbizobium that can infect and form nodules on the roots of leguminous plants. Before the patent, growing leguminous plants with the necessary capacity for nitrogenfixation required using individual strains of Rbizobium for different kinds of plants. The different bacterial strains could not be mixed because they were believed to inhibit each other. The inventor discovered a combination of these bacteria that did not have this mutually inhibitive effect and allowed mixed strains and obtained a composition patent on the mixture of bacterial strains. The Supreme Court held, however, that the mixture was a product of nature, and thus ineligible, because each strain remained unchanged by the mixing and continued to perform its natural function.

The other helpful precedent is the Supreme Court's decision in Diamond v. Chakrabarty (Chakrabarty 1980). In that case, microbiologist Anand Chakrabarty had invented a transgenic bacterium from the genus Psendomonas containing plasmids that coded for the ability to degrade hydrocarbons. The genetically engineered bacterium could break down elements of crude oil and was believed to be valuable in cleaning oil spills. Dr. Chakrabarty had sought method and composition claims, including a composition claim to the bacterium itself. The Supreme Court held that the bacterium was not a product of nature and was patent-eligible. The decision provided important doctrinal lessons. First, patent eligibility is broad, embracing 'anything under the sun that is made by man'. ${ }^{4}$ Second, though products of nature are ineligible, an invention may distinguish itself from a natural product if it has 'markedly different characteristics from any found in nature'.

In its explanation, the Supreme Court drew a direct comparison to its decision in Funk Brothers. Whereas the root nodule bacteria were unchanged and did the same thing in combination that they did individually, Dr. Chakrabarty's engineered bacterium was a new organism that did not occur in nature. It is important to note that this conclusion is a matter of perspective. The Psendomonas host bacterium did do what it had always done, ordinary cellular functions and all. Meanwhile, the plasmids that were spliced into the host bacterium occur naturally, though not in Psendomonas itself, and also did what they had always done: code for hydrocarbon degradation, specifically of camphor and octane. Taken together, however, these two prod- 
ucts of nature became one product that was 'markedly different' enough not to be considered natural. The mixture in Funk Brothers was a combination of bacterial strains, and the mixture in Chakrabarty was a combination of host bacterium and plasmids. The former was a product of nature, the latter was not, and the salient difference seems to have been that the latter resulted in a new organism. In other words, what the relevant unit of observation is can matter a lot.

\subsection{The Myriad case}

In light of these precedents, should isolated DNA sequences be considered products of nature? The district court's decision regarding Myriad's composition claims said yes (Myriad I 2010). Judge Sweet concluded that genes are carriers of biologically important information and that their legal status must therefore be evaluated in informational terms. In that evaluation, DNA sequences reflect the same information in their isolated form as they would in their wild-type form: the same set of nucleotides in the same order encoding the same amino acids. Thus, isolated DNA sequences are not only not 'markedly different' - in the informational sense, they are not different at all. This logic would later echo in the Supreme Court's decision as well.

The Federal Circuit's decision, meanwhile, said no (Myriad II 2011). Unlike the nucleotide chain of the wild-type BRCA1 or BRCA2 gene that occurs in nature, the nucleotide chain of the isolated gene is chemically disconnected from its adjacent nucleotides. In nature, covalent bonds would attach to the 3' and 5' ends of the gene. For the isolated gene, they end in a hydroxyl group and a phosphate group, respectively. As the Federal Circuit explained, this makes the isolated gene a "free-standing" molecule with a "distinctive chemical identity from that possessed by native DNA" (ibid.). This may seem like a technicality, but the Federal Circuit underscored that "a covalent bond is the defining boundary between one molecule and another". As for why this was different enough to be 'markedly different', the court further explained that "genes are in fact materials having a chemical nature and, as such, are best described in patents by their structures rather than their functions" (ibid.) notwithstanding that some may think of molecules, even macromolecules such as DNA, in terms of their functions and uses.

A fortiori, this discussion of why gDNA sequences like the isolated genes of Myriad's patents were not products of nature reflected a similar discussion of why cDNA was not a product of nature, either. cDNA not only had unbonded 3' and 5' ends (just as gDNA did) but also contained only exons: the non-coding introns had been removed. As a result, cDNA did not even correspond in terms of its nucleotide sequence to any naturally occurring nucleic acid. So if gDNA was not a product of nature, cDNA was certainly not a 
product of nature. Both were patent-eligible because, in drawing a comparison between the patented invention and the corresponding product of nature, the relevant unit of observation was chemical structure.

However, the Supreme Court saw things differently. In comparing isolated gDNA sequences for BRCA1 and BRCA2 to the wild-type gDNA sequences of those genes, it was not chemical structure alone that was relevant. Instead, the information contained in the nucleotide sequence was the relevant unit of observation. The reason for this, said the Supreme Court, was that the language of Myriad's own patent claims was expressed not in terms of chemical composition but rather in terms of sequence information. Moreover, the invention over which the patent claims purported to assert ownership did not rely on any chemical change that might have resulted from the cleaving of covalent bonds to produce an isolated section of gDNA. The claims focused on the genetic code reflected in the BRCA1 and BRCA2 gene sequences, and that would be the way in which their status as products of nature would be evaluated.

This approach prioritized genetic information over chemical structure. By this approach, claims to cDNA would still survive. Structural difference at the 3' and 5' end was the only basis for the patent-eligibility of gDNA, but cDNA differed in both structure and nucleotide sequence. Thus, the removal of introns to produce a new sequence meant that, even under the Supreme Court's more stringent approach, cDNA remained markedly different from the underlying DNA out of which it was transcribed. Indeed, this was essentially the result as well as the approach that the Office of the Solicitor General had counseled from the start.

The decision was highly anticipated and immediately controversial. PUBPAT, the ACLU, and a host of advocacy groups that were aligned with them had pushed for a broader conclusion that DNA sequences that correspond to naturally occurring genes, whether those sequences take the form of gDNA or cDNA, were patent-ineligible products of nature because their nucleotide sequences were determined by nature rather than by human design. The Supreme Court's Myriad decision fell short of that goal by leaving cDNA eligible. Meanwhile, Myriad itself and biotechnology companies that held DNArelated composition patents similar to Myriad's suffered a setback from the patent-ineligibility of claims to isolated gDNA. Those rights were no longer valid, and a great many others could now use those gDNA sequences freely.

The government's position, which prevailed, was widely seen as a compromise to ensure that the building blocks of genetic and genomic innovation were unencumbered and widely available, while the opportunity to recoup investments in developing libraries of cDNA sequences would remain viable for the biotechnology industry. Whether or not this pragmatic policy choice 
was what actually motivated the Supreme Court's decision, it was the result that the decision brought.

\subsection{Myriad overseas: Revisiting the European Biotechnology Directive}

The controversy was not limited to the United States. After the Supreme Court in Chakrabarty announced a broad purview of eligibility for patents in biotechnology, the European Commission in 1982 proposed its own legislative reform in order to make biotechnology-related inventions eligible for patents issued by the European Patent Office (EPO). These efforts culminated in the Directive on the Legal Protection of Biotechnological Inventions -commonly known as the European Biotechnology Directive - and were aimed at keeping the European Union competitive with the United States as to incentives for innovation, such as in biotechnology, requiring long-term capital investment. The EPO implemented the European Biotechnology Directive as part of the European Patent Convention, the multilateral treaty that authorizes the EPO to consolidate the patent application process in member countries across Europe.

Over its decade-and-a-half-long deliberations, the Parliament of the European Union had worked out a fairly specific position about whether and when patents can be issued over inventions related to DNA and other genetic materials. This was a different posture than that of the United States. The apparently broad mandate of Chakrabarty had come from a politically insulated Supreme Court, and so its stability over time depended on different institutional forces than did the legislative consensus that undergirded the European Biotechnology Directive.

As a result, the dramatic reversal in the Supreme Court's Myriad decision raised the possibility that the greater specificity and greater predictability and clarity of European patent laws on biotechnology made the EU more attractive for investment. For example, Article 5(1) of the European Biotechnology Directive provides as follows:

The human body, at the various stages of its formation and development, and the simple discovery of one of its elements, including the sequence or partial sequence of a gene, cannot constitute patentable inventions.

By contrast, Article 5(2) and 5(3) provide as follow:

An element isolated from the human body or otherwise produced by means of a technical process, including the sequence or partial sequence of a gene, may constitute a patentable invention, even if the structure of that element is identical to that of a natural element. 
The industrial application of a sequence or a partial sequence of a gene must be disclosed in the patent application.

The circumstances in the United States were more nebulous, requiring predictions about what might or might not be considered a product of nature in the future. Guessing wrong meant that large sums of today's investment could be lost tomorrow when others see a desirable but expensive patented technology and try to make it more widely accessible by removing its patent protections. These sorts of potential costs had to be weighed, of course, against benefits such as improved research access to natural products unfettered by exclusive rights. The real uncertainty was whether, on balance, the cost-benefit calculus would enhance net social welfare.

Analytically, the approach of the European Biotechnology Directive was to avoid making patent eligibility dependent on vague constructs such as what counts as a 'product of nature' (or an 'abstract idea' or 'natural phenomenon' - which are also ineligible under U.S. patent law). Instead, the Directive does much line-drawing between what is eligible and what is not. For example, human beings at various phases of development are not eligible for patenting. Other forms of life may be eligible, though they must not be caused to suffer unless there is substantial countervailing medical benefit. Discoveries, scientific theories, and mathematical methods are not considered inventions at all and so are not eligible. And in general, inventions must be of a technical nature and have a technical effect or industrial application in order to be eligible under the European approach. In all, the clarity of the European Biotechnology Directive and of its implementing regulations does not necessarily correspond to broader or more generous patent scope. In fact, much is excluded, but the boundary lines are easier to identify.

For Myriad, this meant that its corresponding European patents on BRCA1 and BRCA2 were adjudicated more straightforwardly on the basis of the relevant European patent law when those patents were challenged in the European Patent Office, rather than lurching from one judicial approach to another regarding the vague product of nature doctrine. Commentator Jessica Lai framed the point in the first major post-Myriad scholarly analysis of the BRCA patents in Europe this way: "neither BRCA1 nor BRCA2 were strongly patented in Europe," but for firms in the biotechnology industry, it is hard to ignore that the European BRCA-related patents largely survived where the U.S. patents did not (Lai 2015).

The flip side of this dynamic is that although enactment of the European Biotechnology Directive reflected sufficient consensus in the European Parliament twenty years ago, popular unease with the patenting of human genes existed then and has only grown since the turn of the century. As Dr. Lai points out, important U.S. Supreme Court decisions can and do influence law and policy in other jurisdictions, especially given the preeminent role of the 
United States in shaping the international patent harmonization agenda. The growing disfavor, even in parts of Europe, for DNA-related patents may find ample support in both the Myriad decision and the subsequent decisions of the lower U.S. federal courts interpreting Myriad.

Taken together, this body of recent American jurisprudence reflects a discernible trend against allowing such patents where, for example, their application is in diagnostic medicine (Eisenberg 2015). For biomedical patents more generally, however, this trend may be somewhat more attenuated in magnitude or at least mixed in its applicability (Rai 2013). In either case, the finite resilience of Chakrabarty and similar judicial precedents is a reminder that legislative milestones such as the European Biotechnology Directive are not immune from reconsideration merely because of their longevity.

\section{Ethical Implications}

Until now, the discussion has traced the legal question of whether exclusive rights can be asserted over DNA sequences through patent law, and the biochemistry and genetics that underlie that legal debate have been scientifically straightforward. In fact, what was really contested in this legal debate with regard to the science was what scientific facts were relevant, and who was best suited to decide what was relevant. The key choice of the Supreme Court's decision in Myriad was to consider DNA not merely as a large molecule that has chemical structure and function but, more profoundly, as a vehicle for important genetic information. This section now evaluates the answer to that legal question in ethical terms. The themes of contested relevance and the power to decide remain important here as well, and are developed further.

\subsection{Expertise and generalism}

At the start of this decade, law professor Peter Lee published an important and wide-ranging paper in the Yale Law Journal applying the 'Two Cultures' thesis first advanced by C.P. Snow in postwar Britain. Snow's argument was that intellectual specialization in the liberal arts and the sciences, respectively, threatened a "gulf of mutual incomprehension" between these two broad segments of academic thought (Snow 1959). Professor Lee's insight, in turn, was that the 'Two Cultures' are a helpful lens through which to understand and evaluate U.S. patent law. The major premise of Professor Lee's paper is that "no matter how elegantly policymakers craft patent law, if generalist 
judges lack the capacity to administer it, the patent system cannot fulfill its objectives" (Lee 2010). This foreshadows, of course, the epistemic debate that would arise in the Myriad case between the more expert but narrowly specialized postures of the Patent Office and the Federal Circuit, on the one hand, and the more authoritative but generalist postures of the Solicitor General and the Supreme Court, on the other.

Professor Lee's thesis suggests a preference that generalism should enjoy primacy. The expert institution has its say, and the generalist institution listens carefully, but the generalist is who decides. So the expert had better be able to translate complex information persuasively. Indeed, this is how such decisions are actually made in practice. Generalist decision makers might choose at various times to give more or less deference to experts further down the chain of authority, but the need to translate complexity cannot be eliminated. The ethical dimension of this translational challenge lies in an interaction between specialists and generalists that remains to be considered: the dialogues between inventors and patent lawyers and among patent lawyers themselves.

Patent lawyers who represent inventors before the Patent Office to secure patent rights over inventions grapple most directly with the 'Two Cultures' problem. As lawyers, they must complete traditional legal training, including reasoning by analogy, inducing general principles from specific cases, and synthesizing conflicting propositions. However, permission to practice before the Patent Office also requires education or experience in a science or engineering discipline. Thus, patent lawyers must also demonstrate proficiency in the scientific method, including developing and testing hypotheses, reasoning quantitatively, and drawing or rejecting causal inferences in accordance with statistical norms.

As Snow and Lee recognized, these two epistemic orientations are far from mutually exclusive, but they do prioritize different modes of thinking, knowing, and - what is especially important - making arguments. Notably, representing clients in the Patent Office is not the only kind of patent lawyering. A great many lawyers negotiate business deals involving patent rights, file or defend patent-related lawsuits in the courts, and engage in a range of patent policy and other patent-related endeavors, all without having any training or epistemic orientation in science or engineering. These all may still reasonably be considered patent lawyers.

Ultimately, all patent lawyers must work in that system of social, political, and legal institutions where legal rights over complex scientific and technological innovation must be reconciled with the more broadly held values from which patent law draws its legitimacy in the first place. Because a patent legally empowers its owner to exclude others from making, selling (or even offering for sale), importing, or using the invention, the most commonly cited 
broader value underlying patent law is innovation in the technological and economic sense. On this view, what matters is whether patents on gene sequences or other DNA-related innovations promote or hinder research and whether they promote or hinder the development of industries to bring that research to market (Contreras \& Deshmukh 2017; Cook-Deegan et al. 2012). This is not the only narrative that bears on gene patenting, however.

Apart from the view of patents as incentives to innovation, additional and often competing views exist as well of broadly held social values that patent law should accommodate (Contreras 2016). One view is that science should be concerned more with fostering collaborative and path-breaking discovery than with pursuing individual profit for incremental advances. Another view is that legal institutions should avoid changing course suddenly or dramatically because a stable institution that respects reliance interests can more effectively encourage those who undertake long-term research investments to view the institution's commitments as credible. Still another view is that broader distributive effects, especially disparate limitations on access, should be taken into account when evaluating patent laws and patent rights because even a system that does everything it should to promote innovation may still be defective if, for example, it prices out vulnerable or otherwise marginalized segments of society from the innovation's benefits.

Among these and other important narratives, some balance must be struck, and the recurring question of who decides comes again to the fore. However, beyond simply pointing to who decides in contemporary society, it is helpful to consider, in accordance with a well-developed system of philosophical legal ethics, how to decide who decides.

\subsection{How to decide who decides}

In their recent and highly readable intellectual history of legal ethics, David Luban and Bradley Wendel describe that well-developed system as an ongoing succession (Luban \& Wendel 2017). The First Wave of legal ethics was rooted in moral philosophy and concerned primarily with the problem that a lawyer's zealous, one-sided advocacy to the client might make the lawyer complicit in the client's wrongs, inflict harms upon third parties, and reinforce structures of social power that reward unethical or otherwise undesirable actions. The Kantian view of people as ends in themselves, influential in Western thought, seemed to be at odds with the lawyer's apparent duty to treat the client as the end and the lawyer as the means. In response, First Wave legal ethics scholars attacked the 'neutral partisanship' conception that a lawyers should remain agnostic to the morality of the client's positions or demands, should dispassionately show partisanship toward the client's inter- 
ests, and should be exempt from moral criticism for their role as mere intermediaries (Simon 1978).

Thus, when a lawyer who majored in biochemistry during college, graduated from law school, and now works at a patent law firm receives a request from a client biotechnology company to file applications in the Patent Office on isolated gene fragments that the client has sequenced, an ethical choice confronts the lawyer. Should she draft the patent application and the claims to maximize her client's potential future revenues through licensing and, if needed, litigation? Should she try to balance her client's desire for revenue with the interests of academic research, e.g., by drafting claims that would cover industrial applications but not necessarily university research? Should she go even further and, either through claim drafting and the Patent Office process or by vigorous advice to the client, try to ensure that as broad a share of society as possible has access to the diagnostic or other benefits of the gene sequence? A First Wave legal ethicist would likely say that the answers to some of these questions are yes; that the primacy of the traditional lawyerclient relationship must yield in difficult cases to more general ethical requirements that apply to all individuals alike; and that the reason for this reconception is essentially moral in nature.

The Second Wave of legal ethics, by comparison, was rooted more in political philosophy. Rather than situating the lawyer in an individual moral stance, it was concerned primarily with the lawyer's unavoidably institutional role. The lawyer is not just another person with universal ethical obligations but is "part of a scheme of political institutions and practices that has the governance of the community as its end" (Luban \& Wendel 2017). This institutional role is especially important in pluralist societies where the whole assumption of homogenous moral norms is inapt. Such societies require what influential legal theorists Henry Hart and Albert Sacks called institutional settlement, a reconciliation of competing or conflicting normative judgments (Eskridge \& Frickey 1993). For this reconciliation to have meaning, lawyers - indeed, all members of society - must respect the results of the settlement process even if those results are unpleasant in individual cases. Conversely, for the process of securing institutional settlement to have legitimacy, it must consider a broad enough range of normative perspectives that the result can reasonably be considered deliberative and just.

Thus, for our patent lawyer whose client seeks patents on isolated gene fragments, ethical choices remain. The Second Wave legal ethicist would point to the responsibility of the Patent Office and Solicitor General to take the concerns of impoverished patients into account when formulating policy. This consideration could not take place in a vacuum, nor does it have to. Government agencies with policy authority over access to healthcare, such as the Centers for Medicare \& Medicaid Services within the Department of 
Health and Human Services, might properly be included in an executivebranch discussion with the Patent Office about the broader social effects of gene-related patents. So might the Food and Drug Administration, which regulates clinical testing of pharmaceuticals and whose lawyers and policy advisors are familiar with the interactions of patent law with drug safety and efficacy.

Importantly, the institutionally political (rather than individually moral) stance of Second Wave legal ethics does not let our patent lawyer off the hook. In addressing arguments to various audiences such as executive agencies or federal courts, she remains obligated to educate herself and to educate and advise her client about various pluralist perspectives that are likely to bear on the client's interests. This obligation was crystallized starkly during the Myriad case in how the Federal Circuit and the Supreme Court worked to fulfill their respective responsibilities not only to determine which view of the product of nature doctrine would promote innovation or hinder university research or distribute access to breast cancer diagnostics one way or the other, but also to determine which of these objectives were worth pursuing at the expense of which others.

\subsection{The dichotomy in Myriad}

Recognizing these obligations recalls our starting point: the Justice Department and its magic microscope in April 2011. By this point, we can identify all the relevant actors as well as the epistemic orientations that underpin their respective arguments and decisions. Myriad Genetics, the innovator seeking to protect its patents and revenue streams, had solved a scientific problem and cast its solution in scientific terms. Myriad's orientation was more technical in its nature and more narrowly specialized in its expertise. The Patent Office had taken a similarly technical and specialized posture in granting Myriad's patents. This was true of the agency leadership who had previously deemed genetic sequences patentable and would later defend that decision in executive-branch deliberations. It was also true of the patent examiners who had evaluated Myriad's actual applications under then-existing laws and found them to be deserving of patents.

By contrast, PUBPAT and the ACLU were recasting Myriad's scientific solution in broader terms. In their view, the ability of molecular biologists to correlate genetic mutations with elevated risks of developing breast and ovarian cancer was only the beginning. Unless and until that scientific contribution could be met with legal and regulatory policy that ensured widespread usage of the invention as well as economic and fiscal policy that ensured widespread access by patients across the socioeconomic spectrum, the justifications for conferring exclusive patent rights on life-saving diagnostic meth- 
ods were not satisfied. Thus, PUBPAT and the ACLU's orientation was much more broadly generalist.

Judge Sweet in the Southern District of New York was similarly generalist, as federal district judges tend to be. The Federal Circuit is a high-profile exception to this rule given its more specialized patent-related responsibilities, but the Supreme Court again restores the norm of favoring generalism. Executive branch orientation follows a similar upward trend toward generalism. Subordinate agencies are specialized according to their respective missions whereas high-level officials such as the Solicitor General are broadly generalist. In the middle are agency heads, who must translate between political superiors and technical employees.

Thus, at each step in a dispute, one may expect different chances of success depending on one's own orientation and that of the audience. PUBPAT and the ACLU found a favorable generalist audience in the district court, but Myriad and the Patent Office found a favorable specialist audience at the Federal Circuit. The Solicitor General and the Supreme Court had no easy task in disentangling the perspectives that had percolated up toward them. The Solicitor General's office had to come to grips with its lack of relevant scientific expertise relative to the Patent Office (and other agencies such as the NIH), just as the Patent Office had to come to grips with its lack of relevant authority. A similar dynamic described the generalist but authoritative Supreme Court and the expert but subordinate Federal Circuit.

In this kind of complex and multi-faceted dispute, it is not enough for our hypothetical patent lawyer simply to say, 'I have studied biochemistry and law, and because this isolated DNA sequence is a molecule, patent law's familiar rules on chemical inventions govern'. That may turn out to be the conclusion, as it was in the Federal Circuit's decision. However, our brief ethical analysis, the Solicitor General's position, and the Supreme Court's decision suggest that this insular view is not a proper starting point. As Myriad's lawyers as well as PUBPAT and the ACLU's lawyers discovered as the dispute progressed, this insular view excludes competing perspectives that may lack scientific or doctrinal expertise but nevertheless have authority from broader social values that the patent system should accommodate. These considerations also underscore the importance of Professor Lee's overall argument, that the patent system cannot fulfill its objectives unless the expertise of those inside the system can be translated effectively to the generalists who must administer it. 


\section{Conclusion}

This brief and selective glimpse into one of the more contentious and farreaching disputes over the ethical, legal, and social implications of genetic and genomic innovation has identified a few recurring themes that merit further study. One is the ongoing tension between experts and non-expert generalists in the often zero-sum sphere of political and social decision making. For reasons of institutional settlement and broader reasons of democratic legitimacy that are outside the scope of this discussion, generalists largely hold ultimate authority in the patent system.

However, the limits on expert input should not be taken as a sign that expertise is unimportant. If anything, the vesting of decisional power in generalists means that scientists, engineers, and others who have cultivated technological expertise bear a correspondingly greater responsibility to engage, educate, and persuade those outside their respective disciplines about what the facts are and how those facts matter.

Another recurring theme, related to the translational obligation of experts, is that the ethical stance of those with training in the natural sciences should extend beyond individual demands of moral philosophy, important though they are. It should further consider institutional demands of political philosophy as well. As with generalism, the salient lesson is one of engagement.

Such engagement may take the form of seeking advanced training in interdisciplinary problems. It may also take the form of being purposeful about the kinds of financial, social, professional, or other incentives to which to respond. Because the science of biochemistry, and the particularly compelling potential of genetics and genomics, are so intimately tied to basic questions of human health and self-determination, these calls to engagement apply with special force to those in the chemistry-related disciplines.

\section{Notes}

The details of that patent policy matter are discussed in Section 2.2 below.

2 In patent law, a 'product of nature' is not eligible for patenting, though a humanmade invention can be patent-eligible even if derived from a natural product - if the invention is 'markedly different' from what occurs in nature.

3 A patent is a stylized document with distinct sections and parts. The 'claims' of a patent are the statements at the end that specify what the inventor actually invented. Taken together, the claims in a patent must all point to a single invention, but each claim represents a slightly different embodiment of that invention. 
4 This language is most closely associated in patent law with the Chakrabarty decision but was actually part of the legislative history of the 1952 Patent Act itself.

\section{Further Reading}

The following papers offer an overview of important issues that remain after the Supreme Court's Myriad Genetics decision: Cook-Deegan 2012, Rai \& Cook-Deegan 2013, Sherkow \& Greely 2015. These issues include the growing usage of trade secrecy over clinical data, the legal outlook for wholegenome sequencing, and historical lessons about how genes first came under the purview of the patent system.

\section{References}

Contreras, J.L.: 2016, 'Narratives of Gene Patenting', Florida State University Law Review, 43 (4), 1133-1200 [available online: ssrn.com/abstract $=2485681$, accessed 8 May 2020].

Contreras, J.L. \& Deshmukh, V.G.: 2017, 'Development of the Personal Genomics Industry', in: S. Bouregy, et al. (eds.), Genetics, Ethics and Education, Cambridge: Cambridge Univ. Press [available online: $s s r n$.com/abstract $=3092313$, accessed 8 May 2020].

Cook-Deegan, R.M.: 2012, 'Law and Science Collide Over Human Gene Patents', Science, 338 (6108), 745-747, [available online: science.sciencemag.org/content/338/6108/745, accessed 8 May 2020].

Cook-Deegan, R.M.; Conley, J.M.; Evans, J.P. \& Vorhaus, D.B.: 2012, 'The Next Controversy in Genetic Testing: Clinical Data as Trade Secrets?', European Journal of Human Genetics, 21 (6), 585-588 [available online: www.ncbi.nlm.nih.gov/pubmed/23150081, accessed 8 May 2020].

Eisenberg, R.S.: 2015, 'Diagnostics Need Not Apply', Boston University Journal of Science \& Technology Law, 21 (2), 256-286 [available online: ssrn.com/abstract $=2631679$, accessed 8 May 2020].

Eskridge Jr., W.N. \& Frickey, P.P.: 1994, 'The Making of the Legal Process', Harvard Law Review, 107, 2013-2055 [available online: digitalcommons.law.yale.edu/fss papers/3843/, accessed 8 May 2020.

Lai, J.C.: 2015, 'Myriad Genetics and the BRCA Patents in Europe', UC Irvine Law Review, 5 (5), 1041-1076 [available online: scholarship.law.uci.edu/ucilr/vol5/iss5/5/.

Lee, P.: 2010, 'Patent Law and the Two Cultures', Yale Law Journal, 120 (1), 1-83 [available online: digitalcommons.law.yale.edu/ylj/vol120/iss $1 / 1 /$, accessed 8 May 2020].

Luban, D. \& Wendel, W. B.: 2017, 'Philosophical Legal Ethics: An Affectionate History', The Georgetown Journal of Legal Ethics, 30 (3), 337-364 [available online: scholar- 
ship.law.cornell.edu/cgi/viewcontent.cgi? article=2686\&context $=$ facpub, accessed 8 May 2020].

Rai, A.K.: 2013, 'Biomedical Patents at the Supreme Court: A Path Forward', Stanford Law Review Online, 66, 111-117 [available online: scholarship.law.duke.edu/faculty_scholarship/3142/, accessed 8 May 2020].

Rai, A.K. \& Cook-Deegan, R.M.: 2013, 'Moving Beyond Isolated Gene Patents', Science, 341 (6142), 137-138 [available online: science.sciencemag.org/content/341/6142/137, accessed 8 May 2020].

Sherkow, J.S. \& Greely, H.T.: 2015, 'The History of Patenting Genetic Material', Annual Review of Genetics, 49, 161-182 [available online: ssrn.com/abstract $=2713761$, accessed 8 May 2020].

Simon, W.H.: 1978, 'The Ideology of Advocacy: Procedural Justice and Professional Ethics', Wisconsin Law Review, 1978, 29-144.

Snow, C.P.: 1959, The Two Cultures (London: Cambridge University Press) [available online: s-f-walker.org.uk/pubsebooks/2cultures/Rede-lecture-2-cultures.pdf, accessed 8 May 2020].

\section{Legal Documents}

European Parliament and the Council of the European Union: 1998, Directive 98/44/EC (European Biotechnology Directive) [bit.ly/2C4uiuM].

Supreme Court of the United States: 1948, Funk Bros. Seed Co.. v. Kalo Inoculant Co. $\begin{array}{llll}\text { (Funk } \quad 333 & \text { Bros.), } & & \\ & \end{array}$ [www.leagle.com/decision/1948460333us1271450].

Supreme Court of the United States: 1980, Diamond v. Chakrabarty (Chakrabarty), 447 U.S. 303 [www.leagle.com/decision/1980750447us3031737].

Supreme Court of the United States: 2013, Ass'n for Molecular Pathology v. Myriad Genetics, Inc. (Myriad IV), $133 \quad$ S. Ct. 2107 [www.leagle.com/decision/insco20130613e08].

U.S. Court of Appeals for the Federal Circuit: 2011, Ass'n for Molecular Pathology v. Myriad Genetics, Inc. (Myriad II), $653 \quad$ F.3d 1329 [www.leagle.com/decision/infco20110729000t].

U.S. Court of Appeals for the Federal Circuit: 2012, Ass'n for Molecular Pathology v. Myriad Genetics, Inc. (Myriad III), $689 \quad$ F.3d 1303 [www.leagle.com/decision/infco20120816212].

U.S. District Court for the Southern District of New York: 2010, Ass'n for Molecular Pathology v. Myriad Genetics, Inc. (Myriad I) [www.leagle.com/decision/infdco20100330948].

U.S. Patent No. 5,693,473: 1997, 'Linked breast and ovarian cancer susceptibility gene' [patents.google.com/patent/US5693473].

U.S. Patent No. 5,709,999: 1998, 'Linked breast and ovarian cancer susceptibility gene' [patents.google.com/patent/US5709999].

U.S. Patent No. 5,710,001: 1998, '17q-linked breast and ovarian cancer susceptibility gene' [patents.google.com/patent/US5710001].

U.S. Patent No. 5,747,282: 1998, '17Q-linked breast and ovarian cancer susceptibility gene' [patents.google.com/patent/US5747282].

U.S. Patent No. 5,753,441: 1998, '170-linked breast and ovarian cancer susceptibility gene' [patents.google.com/patent/US5753441]. 
U.S. Patent No. 5,837,492: 1998, 'Chromosome 13-linked breast cancer susceptibility gene' [patents.google.com/patent/US5837492].

U.S. Patent No. 6,033,857: 2000, 'Chromosome 13-linked breast cancer susceptibility gene’ [patents.google.com/patent/US6033857].

Saurabh Vishnubhakat:

School of Law and Dwight Look College of Engineering, Texas AEM University,U.S.A.;sv10@law.tamu.edu 